\title{
THE SMALLEST WORKERS IN REGENERATIVE MEDICINE: STEM CELL-DERIVED EXOSOMES
}

Ozer Oner ${ }^{1,2,3}$, Suleyman Gokhan Kara ${ }^{1,2,4}$, Insan Burak Karakaya ${ }^{1,2}$, Ayla Eker Sariboyaci 1,2, Onur Uysal 1,2, Sibel Gunes ${ }^{1,2}$, Huseyin Avci, ${ }^{1,2,5,6}$

'Cellular Therapy and Stem Cell Production Application and Research Centre, ESTEM, Eskisehir Osmangazi University, Eskisehir, Turkey ${ }^{2}$ Department of Stem Cell, Institute of Health Sciences, Eskisehir Osmangazi University, Eskisehir, Turkey ${ }^{3}$ Suhut Vocational School of Health Services, Afyonkarahisar Health Sciences University, Afyonkarahisar, Turkey ${ }^{4}$ Department of Emergency Medicine, Eskisehir City Hospital, Eskisehir, Turkey ${ }^{5}$ Department of Metallurgical and Materials Engineering, Eskişehir Osmangazi University Eskişehir, Turkey

${ }^{6}$ Translational Medicine Research and Clinical Center, Eskisehir Osmangazi University, Eskisehir, Turkey

\section{Abstract:}

Extracellular vesicles (EVs) are secreted by cells into the extracellular space, which first discovered in 1967 as platelet dust. In recent years, the analysis of EVs treatment for various diseases has emerged in the studies to understand these vesicles' origin and biological functions. According to their size, biogenesis, content, release pathways and function, EVs have three main subtypes: microvesicle (MV), exosome (EX) and apoptotic body. EVs are found in all body fluids, including urine, plasma, and physiological fluids such as bronchial lavage. In addition, it is secreted by many cell types such as dendritic cells, B cells, T-cells, mast cells, tumour cells, and sperm. This review investigates the studies using stem cell-derived EVs in numerous clinical and preclinical research.

Keywords: Extracellular Vesicles, Stem Cell, Exosome, Regeneration, Regenerative Medicine.

Özet:

Ekstraselüler veziküller (EV), ilk olarak 1967'de trombosit tozu olarak keşfedilen, hücreler tarafından hücre dışı boşluğa salgılanan lipide bağı veziküllerdir. Son yıllarda bu veziküllerin kökeninin ve biyolojik işlevlerinin anlaşılması için yapılan araştırmalarda EV'lerin çeşitli hastalıkların tedavilerinde kullanılabileceği fikri ortaya çıkmıştır. EV'lerin biyogenezlerine, salınım yollarına, boyutlarına, içeriğine ve işlevlerine göre farklılaşan, mikroveziküller (MV'ler), eksozomlar (EX) ve apoptotik cisimler olmak üzere üç ana alt tipi vardır. EV'ler; idrar, plazma ve bronşiyal lavaj gibi fizyolojik sıvılar dahil tüm vücut sıvılarında bulunurlar. Bunun yanında, B hücreleri, dendritik hücreler, mast hücreleri, T-hücreleri, tümör hücreleri, sperm gibi pek çok hücre tipi tarafından da salgılandığı gösterilmiştir. Bu derlemede çok sayıda klinik ve preklinik çalışmada kullanılan kök hücre kaynaklı EV'lerin terapötik etkinliğini gösteren çalışmaları derledik.

Anahtar Kelimeler: Ekstrasellüler veziküller, Kök Hücre, Eksozom, Rejenerasyon, Rejeneratif Tıp.

Correspondence Address : Ozer Oner Cellular Therapy and Stem Cell Production Application and Research Centre, ESTEM, Eskisehir Osmangazi University, Eskisehir, Turkey ozeroner@yandex.com

Please cite this article in press at: Oner O., Kara S.G., Karakaya I.B., Sariboyaci A.E., Uysal O., Gunes S., Hüseyin Avcı H., The Smallest Workers in Regenerative Medicine: Stem Cell-Derived Exosomes, Journal of Medical Innovation and Technology, 2021; 3 (2):58-67 doi: 10.51934/jomit.1016923
ORCID ID of the authors: 0.0. 0000-0001-5352-7437, S.G. 0000-0002-7152-5643, I.B.K. 0000-0001-7634-0771, A.E.S. 0000-0003-4536-9859, 0.U. 0000-0001-6800-

5607, S.G. 0000-0003-0846-1170, H.A. 0000-0002-2475-1963 


\section{Introduction}

Besides the hormones and neurotransmitters released from the secretory vesicles of specialized cells, all the cells can secrete various membrane vesicles known as the extracellular vesicle (EV). This process has been preserved in evolutionary processes from bacteria to humans (1).

According to their size, release pathways, biogenesis, and function, EVs have three main subtypes: microvesicle (MV), exosome (EX) and apoptotic body. MVs are large vesicles formed by membrane budding, apoptotic bodies occur by bubbling into senescent or dying cells, and EXs are the smallest vesicles released from cells by the multivesicular endosomal route. EXs are, in general, 40-100 nm in diameter, contain $1.13-1.19 \mathrm{~g} / \mathrm{ml}$ sucrose, and sedimenting at $100,000 \mathrm{xg}$. Its membranes are rich in cholesterol, ceramide, sphingomyelin and lipid. EXs contain protein and RNA. Most EXs have protein sets such as tetraspanins (CD81, CD63 and CD9), TSG101 and Alix, and also contain tissue/cell type-specific proteins that indicate their cellular origin. Removal of unwanted proteins, protein-protein interaction, and intercellular communication in line with the exchange of proteins and genetic materials are among the critical functions of EXs. EXs also play an essential role in the transfer of proteomic and genomic materials between the cells.

EVs carry components of the cells from which they are produced. In animal models and clinical studies, it has been reported that tissue and cellular functions show similar regenerative effects with the cells from which they are produced. The molecular mechanisms of the contents, secretion, uptake and function of EXs form the basis of preclinical studies. This intercellular communication of EVs has brought the view that the desired therapeutic molecule can be loaded and used as a natural drug deliverer (Table 1) (2-4). Stem cells can transform into different cell types, replace injured tissues, and repair at the injury site with a paracrine mechanism of action. Stem cell in vivo studies has been used successfully to treat graft-versus-host disease (GvHD), haematological malignancies, autoimmune diseases, and acute thrombocytopenia (5-7).

Table 1. Properties of exosomes [2].

\begin{tabular}{|l|l|}
\hline Size $(\mathrm{nm})$ & $40-100$ \\
\hline Biogenesis & Exocytosis of multivesicular bodies \\
\hline Markers & CD63, CD81, CD9, Tsg101, Alix, Hsc70. \\
\hline Contents & $\begin{array}{l}\text { Proteins, lipids, mRNA and microRNA and } \\
\text { rarely DNA. }\end{array}$ \\
\hline
\end{tabular}

Whether EXs will be superior to angiogenic drugs, recombinant growth factors, other peptides, and stem cell-based therapies is unclear and is a crucial issue to be investigated. As a result of in vitro and in vivo characterization analyses performed till now, EXs are emerging as a popular cell-free candidate that can be used to overcome many of the challenges posed by using cells as therapeutic agents. It has been used as a source of cell-free therapy in animal models of many tissues damage and diseases $(8,9)$.

\section{Mechanism of Action and Biologıcal Effects of Exosomes}

The genetic material of EXs and MVs is transferred locally and systematically. EV-mediated therapeutic effects are thought to be due to two different mechanisms: First; EVs released from damaged tissues can act on local stem cells and regulate the release of regenerative microvesicles for tissue repair (10). Latter; local stem cells around damaged or degenerated tissues can produce microvesicles to stimulate regeneration, re-enter the cell cycle near damaged tissues and enable dedifferentiation.

Investigating the relationship between wound repair and SC-EV in preclinical studies contributes to paving the way for SC-EVs in clinical studies (11-13). Preclinical studies have demonstrated that $\mathrm{SC}-\mathrm{EV}$ s may repair tissue damage by maintaining stemness, induction of regeneration, inhibition of apoptosis, and immunoregulation (Table 2).

SC-EVs can protect against cell apoptosis and reduce tissue damage. Human umbilical cord-derived mesenchymal stem cell extracellular vesicles (hUC-MSC-EVs) can carry antioxidant enzymes, and manganese superoxide dismutase in mitochondria inhibit oxidative stress-induced hepatocyte apoptosis and protect against hepatic Ischaemia-Reperfusion injury (IRI) in rats (14-17).

\section{Stem Cell Culture for Extracellular Vesicle Production}

\subsection{Stem Cell Selection}

The secretion of EVs is also affected by the senescence of MSCs (18-21). Abello et al. (2019), hUC-MSC-EXs gadolinium lipid (GdL-EXs) or infrared dye in tumour-bearing mice, 1,1'-dioctadecyl-3,3,3',3'-tetramethylindotricarbocyanine iodide (DiR-EXs), analyzed the biodistribution of EXs by labelling them (22). Intravenous infusion of lower doses of EV showed relatively higher hepatic accumulation compared to higher doses $(22,23)$ (Fig. 1). 
Table 2. Experimental model diseases treated with different stem cell-derived EVs.

\begin{tabular}{|c|c|c|c|c|c|}
\hline Indication & Species & $\begin{array}{l}\text { EV Sour- } \\
\text { ces }\end{array}$ & Main outcome & Mechanism & Reference \\
\hline $\begin{array}{l}\text { Traumatic brain } \\
\text { injury (TBI) }\end{array}$ & Rat & $\begin{array}{l}\text { Human } \\
\text { AdMS- } \\
\text { C-EXs }\end{array}$ & $\begin{array}{l}\text { Improvement of motor be- } \\
\text { havior function and cortical } \\
\text { brain injury }\end{array}$ & Delivering MALAT1 & {$[24]$} \\
\hline Stroke & Rat & $\begin{array}{l}\text { Rat BMS- } \\
\text { C-EXs }\end{array}$ & Neurite remodeling & Neurogenesis & {$[25]$} \\
\hline Alzheimer's disease & Mouse & $\begin{array}{l}\text { EXs from } \\
\text { hypoxi- } \\
\text { a-stimula- } \\
\text { ted } \\
\text { BMSCs }\end{array}$ & $\begin{array}{l}\text { Learning and memory abi- } \\
\text { lities }\end{array}$ & $\begin{array}{l}\text { Restoration of synaptic } \\
\text { dysfunction and regulation } \\
\text { of inflammatory responses } \\
\text { through miR-21 }\end{array}$ & {$[26]$} \\
\hline $\begin{array}{l}\text { Spinal cord injury } \\
\text { (SCI) }\end{array}$ & Rat & BMSC-EXs & $\begin{array}{l}\text { Improvement of functional } \\
\text { behavioral recovery effects }\end{array}$ & $\begin{array}{l}\text { Activation of A1 neurotoxic } \\
\text { reactive astrocytes }\end{array}$ & [27] \\
\hline Spinal cord injury & Rat & $\begin{array}{l}\text { Human } \\
\text { BMSC-EVs }\end{array}$ & $\begin{array}{l}\text { Inflammatory response, } \\
\text { improved motor function, } \\
\text { enhanced mechanical sensi- } \\
\text { tivity threshold }\end{array}$ & uncertain & {$[28]$} \\
\hline Spinal cord injury & Mouse & $\begin{array}{l}\text { hucMS- } \\
\text { C-EXs }\end{array}$ & $\begin{array}{l}\text { Improving functional reco- } \\
\text { very }\end{array}$ & Decreases inflammation & [29] \\
\hline $\begin{array}{l}\text { Myocardial infar- } \\
\text { ction }\end{array}$ & Mouse & iPSC-EVs & $\begin{array}{c}\text { Preservation of } \\
\text { viable myocardium }\end{array}$ & $\begin{array}{l}\text { Delivery of ESC specific } \\
\text { miR-294 }\end{array}$ & {$[30]$} \\
\hline $\begin{array}{l}\text { Myocardial infar- } \\
\text { ction }\end{array}$ & Mouse & $\begin{array}{l}\text { Mouse } \\
\text { ESC-EXs }\end{array}$ & $\begin{array}{c}\text { Resurgence of cardiac proli- } \\
\text { ferative } \\
\text { response }\end{array}$ & Delivering miR-294 & {$[31]$} \\
\hline $\begin{array}{l}\text { Myocardial infar- } \\
\text { ction }\end{array}$ & Mouse & $\begin{array}{c}\text { Mouse } \\
\text { BMSC-EVs }\end{array}$ & Improving cardiac function & Delivering miR-210 & {$[32]$} \\
\hline $\begin{array}{l}\text { Myocardial infar- } \\
\text { ction }\end{array}$ & Mouse & $\begin{array}{c}\text { EXs deri- } \\
\text { ved from } \\
\text { hypoxi- } \\
\text { a-stimula- } \\
\text { ted } \\
\text { BMSC }\end{array}$ & $\begin{array}{l}\text { Better cardiac } \\
\text { functions recovery }\end{array}$ & Delivering miR-210 & {$[33]$} \\
\hline Lung injury & Mouse & $\begin{array}{c}\text { Human } \\
\text { BMSC-EVs }\end{array}$ & $\begin{array}{l}\text { Reduces pulmonary vascular } \\
\text { permeability }\end{array}$ & $\begin{array}{c}\text { Modulating cytoskeletal } \\
\text { signaling }\end{array}$ & [34] \\
\hline Acute lung injury & Mouse & $\begin{array}{l}\text { Human } \\
\text { BMSC-M- } \\
\text { Vs }\end{array}$ & $\begin{array}{l}\text { Reduces pulmonary } \\
\text { capillary permeability }\end{array}$ & $\begin{array}{l}\text { Delivering Angiopoietin-1 } \\
\text { mRNA and immune } \\
\text { regulation } \\
\end{array}$ & {$[35]$} \\
\hline $\begin{array}{c}\text { Neonatal hyperoxic } \\
\text { lung injury }\end{array}$ & Rat & $\begin{array}{l}\text { hUCB-MS- } \\
\text { C-EVs }\end{array}$ & $\begin{array}{l}\text { Reduces impaired alveolari- } \\
\text { zation and angiogenesis }\end{array}$ & Transfer of VEGF protein & {$[36]$} \\
\hline Liver injury & Mouse & $\begin{array}{c}\text { Mouse } \\
\text { BMSC-EVs }\end{array}$ & $\begin{array}{l}\text { Increase the mRNA expres- } \\
\text { sion of anti-inflammatory } \\
\text { cytokines }\end{array}$ & $\begin{array}{l}\text { Immunosuppression and } \\
\text { immune protection }\end{array}$ & {$[37]$} \\
\hline
\end{tabular}




\begin{tabular}{|c|c|c|c|c|c|}
\hline $\begin{array}{c}\text { Renal } \\
\text { ischemia/reperfu- } \\
\text { sion } \\
\text { injury }\end{array}$ & Rat & $\begin{array}{l}\text { hiPSC-M- } \\
\text { SC-EVs }\end{array}$ & $\begin{array}{c}\text { Decrease serum levels of } \\
\text { creatinine and urea nitrogen }\end{array}$ & $\begin{array}{l}\text { Exosomal SP1 activating the } \\
\text { expression of SK1 and the } \\
\text { generation of S1P }\end{array}$ & {$[42]$} \\
\hline $\begin{array}{l}\text { Rejuvenation of } \\
\text { skin }\end{array}$ & $\begin{array}{l}\text { Human } \\
\text { skin } \\
\text { tissues }\end{array}$ & $\begin{array}{l}\text { hUCB-MS- } \\
\text { C-EXs }\end{array}$ & $\begin{array}{l}\text { Increase expressions of } \\
\text { Collagen I and Elastin }\end{array}$ & Uncertain & {$[44]$} \\
\hline Wound healing & Mouse & $\begin{array}{l}\text { hucMS- } \\
\text { C-EXs }\end{array}$ & $\begin{array}{l}\text { Decrease scar formation and } \\
\text { myofibroblast accumulation }\end{array}$ & $\begin{array}{l}\text { Transfer of specific microR- } \\
\text { NAs and suppression of TGF- } \beta \\
\text { /Smad2 pathway }\end{array}$ & {$[45]$} \\
\hline Osteoporosis & Rat & $\begin{array}{l}\text { hiPSC-M- } \\
\text { SC-EXs }\end{array}$ & Preventing bone loss & $\begin{array}{c}\text { Activation of the PI3K/Akt } \\
\text { signaling pathway }\end{array}$ & {$[41]$} \\
\hline Stabilized fracture & Rat & $\begin{array}{l}\text { hucMS- } \\
\text { C-EXs }\end{array}$ & $\begin{array}{l}\text { Increase angiogenesis and } \\
\text { bone healing }\end{array}$ & $\begin{array}{l}\text { HIF-1alpha mediated promo- } \\
\text { tion of angiogenesis }\end{array}$ & {$[47]$} \\
\hline $\begin{array}{l}\text { Osteogenesis im- } \\
\text { perfecta }\end{array}$ & Mouse & $\begin{array}{c}\text { Murine } \\
\text { BMSC-EVs }\end{array}$ & Facilitating bone growth & Delivery of miRNAs & {$[48]$} \\
\hline
\end{tabular}




\section{Use of Stem Cell-Derived Exosomes in Treatment}

\subsection{Exosomes in Neurological Diseases}

In recent years, it has been reported that EXs are effective in the pathogenesis of neural diseases. E.g., EXs are released from neurons, astrocytes and glial cells to facilitate different functions such as removing unwanted stress proteins and amyloid fibril formation. EXs containing a-synuclein have been shown to induce cell death in neuronal cells, suggesting that EXs potentiate and increase Parkinson's disease pathology. Again, in Alzheimer's disease, $\beta$-amyloid is released in association with EXs (24).

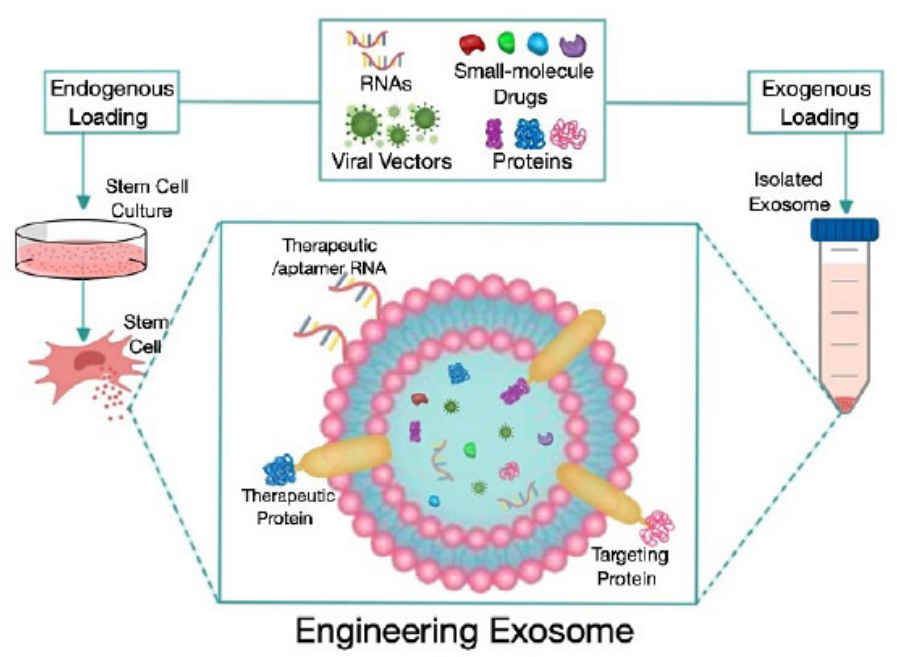

Figure 1. Engineering EVs. Extracellular vesicles (EVs) can provide therapeutic assets, including proteins, RNAs, oncolytic viruses, and small molecule drugs by endogenous loading during EV biogenesis or by exogenous loading after EV isolation. Engineered EVs can express targeted peptides or therapeutic proteins on their surface and bind aptamers or therapeutic RNAs via RNA-binding proteins.

In animal models of brain injury, systemic administration of SC-EXs has been shown to reduce neuroinflammation. (25-27). Traumatic spinal cord injuries can cause clinical conditions up to complete loss of motor and sensation in the lower extremities $(28,29)$. Sun et al. $(2018)$, in a study on rats, showed that UC-MSC-EXs support functional recovery in spinal cord injuries by reducing inflammation (30). Liu et al. (2021) reported that MSC-EVs pretreated with melatonin recovered the traumatic spinal cord injury with NRF2 stabilization (19).

\subsection{Exosomes in Cardiovascular Diseases}

The proliferation abilities of cardiomyocytes usually are pretty poor (31-33). Sun et al. (2018), in a study, conducted, in an animal model of dilated cardiomyopathy induced by doxorubicin: They have resulted that BM-MSC-EXs improved cardiac function, inhibited cardiac dilation, attenuated cardiomyocyte apoptosis, decreased the number of pro-inflammatory macrophages in the infiltration zone and the expression of inflammatory factors (34).

\subsection{Exosomes in Lung Diseases}

Potter et al. (2018) showed that BM-MSC-EVs could significantly reduce pulmonary vascular permeability induced by hemorrhagic shock in mice through regulation of cytoskeletal signalling (35). In another study, Tang et al. (2017) showed that BM-MSC-MVs, administering angiopoietin-1 (Ang-1) mRNAs to mice, can support the stability of the pulmonary vasculature and reduce inflammation in the lungs (36).

On the other hand, Sengupta et al. (2020) conducted a phase I clinical study showing that BM-MSC-EXs can be used safely in lung damage due to COVID-19 (37). With the increase in clinical studies, it is predicted that SC-EXs will enter our daily routine in respiratory system diseases.

\subsection{Exosomes in Gastrointestinal Diseases}

\subsubsection{Intestines}

Inflammatory bowel diseases (IBD) are considered chronic, recurrent inflammatory diseases that can affect any part of the gastrointestinal tract. IBD includes two diseases, Crohn's disease and ulcerative colitis. Although both diseases usually have similar clinical manifestations, they affect different parts of the gastrointestinal tract, and the degree of intestinal wall inflammation may differ (38).

There is evidence that EXs play a role in the pathogenesis of IBD. Macrophage pyroptosis, a cell death process after inflammatory activation of NOD-like receptor family pyrin domain-containing 3 (NLRP3), is thought to be part of the cause of an abnormal immune response in IBD pathogenesis. Macrophage pyroptosis plays an essential regulatory role in reducing colitis by hUC-MSC-EXs. Cai et al. (2021), in their in vivo experiments, showed that hUC-MSC-EXs inhibited the activation of NLRP3 inflammations in the mouse colon and inhibited the secretion of IL-1 $13, \mathrm{IL}-18$ and Caspase-1 cleavage, resulting in a decrease in cell pyroptosis (39). Barnhoorn et al. (2020) demonstrated that local application of BM-MSC-EX as a cell-free substitute for MSC therapy in an animal model of IBD reduces intestinal epithelial damage by stimulating epithelial regeneration (40). 


\subsubsection{Liver}

Studies have shown that SC-EVs can treat liver diseases by the administration of various active molecules. In animal models of liver injury, the use of SC-EXs has been found to reduce injury and increase regeneration (41-43). In addition, studies have revealed that hUC-MSC-EXs can alleviate liver fibrosis in mice by inactivating TGF- $\beta / \mathrm{Smad}$ signalling, reducing collagen deposition and inflammation (44). hUC-MSC-EXs carrying glutathione peroxidase-1 have been shown to protect against liver failure in mice by reducing inflammation and oxidative stress (45).

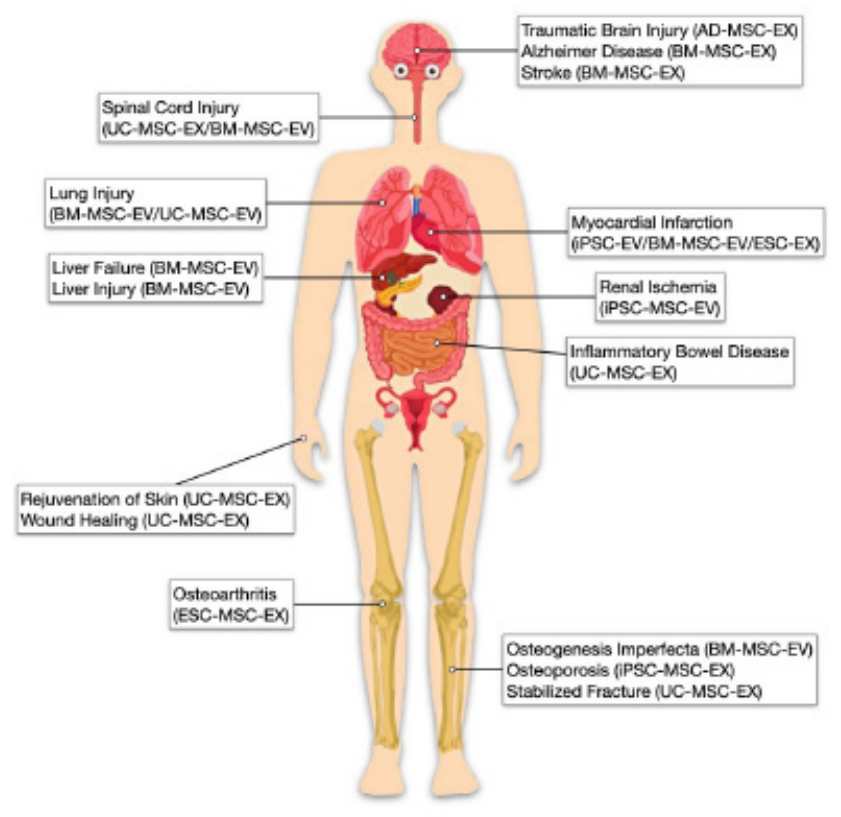

Figure 2. Schematic representation of diseases treatment with exosomes isolated from stem cells through different sources.

\subsection{Exosomes in Ocular Disease}

Preclinical studies have shown that the administration of MSC-EXs can protect against retinal ischemia (46). Shen et al. showed that AD-MSC-EX treatment regulates CSC proliferation, inhibits apoptosis, triggers higher collagen and fibronectin expression, and causes lower expression of matrix metalloproteinases in vitro (47).

\subsection{Exosomes in Renal Diseases}

Preclinical studies have shown that SC-EVs have a positive effect on kidney disease. EVs from human iPSC-derived MSCs (hiPSC-MSC-EVs) transport the specificity protein (SP1) to renal tubular epithelial cells, increasing the expression of sphingosine kinase 1 and inhibiting necroptosis, thus, showed that it prevents renal IRI in rats (48).

Tomasoni et al. (2013) revealed that BMSC-EXs transport insulin-like growth factor 1 (IGF-1) receptor mRNAs to renal tubular epithelial cells in vitro; these mRNAs are then translated into IGF-1 receptor proteins, which can be used to increase the sensitivity of the IGF-1 receptor to local IGF-1 and to treat cisplatin-induced renal tubule injury (49).

\section{Conclusion and Future Perspectives}

SC-EV therapy has made significant progress in regenerative medicine and numerous preclinical trials, laying a solid foundation for clinical transformation practice. It is important to note that selecting an early passage of EV-producing cells, optimizing techniques of cell culture conditions, and using EVs for delivery of genomic materials, proteins, or small-molecule drugs can increase their efficacy against many diseases.

However, we still have a long way to go before the clinical application of EVs. Current research mainly focuses on treating a limited number of diseases in regenerative medicine and oncology using SC-EVs. The functions of SC-EVs should be tested for many other diseases.

High-quality EVs are needed for successful results in studies. To obtain higher quality EVs, it is necessary to select the appropriate culture medium, optimize cell density, cell phenotype, culture time, collection time and other parameters. Furthermore, pre-condition EVs are similarly crucial.

On the other hand, the drug loading potential of SC-EVs should be further investigated. Genome editing techniques currently facilitate EV engineering with different contents and functions but can cause indeterminate mutations in EV-producing cells, affecting the contents and functions of related EVs. Therefore, it is necessary to improve the safety and operability of genome editing techniques, reduce off-target efficiency, and 
ultimately accurately produce EVs with specific functions and components.

It is imperative to improve the drug loading efficiency of EV by novel methods. Exogenous drugs are currently loaded into EVs mainly by electroporation, but the efficacy of this technique is insufficient. Although drug loading efficacy is not proportional to therapeutic efficacy, balancing these two types of efficacies is recommended. Therefore, optimum drug concentrations with the lowest side effects may be preferred to achieve the highest therapeutic efficacy. For this, we still need to increase drug loading efficiency.

The advantages and excellent application potential of SC-EVs are driving the advancement of regenerative medicine. The future development goal should be to optimize EV production conditions, improve production technology, improve yield and quality, measure their therapeutic efficacy, design operations to give EVs more therapeutic functions, and ultimately drive their clinical transformation to benefit people more broadly. On the other hand, it is considered to have potential limitations. For example, EXs are a mixture of biologically active molecules. Some of these molecules may have beneficial effects under certain conditions, while others may have a detrimental effect (e.g., pro-inflammatory). Whether exosomes will be superior to angiogenic drugs or purified recombinant growth factors and other peptides in the context of cell-free approaches for tissue regeneration is unclear and remains an important issue to be explored. 


\section{References}

1. Liu W, Ma Z, Li J, Kang X. Mesenchymal stem cell-derived exosomes: therapeutic opportunities and challenges for spinal cord injury. Stem Cell Research \& Therapy. 2021 Dec 3;12(1).

2. Biancone L, Bruno S, Deregibus MC, Tetta C, Camussi G. Therapeutic potential of mesenchymal stem cell-derived microvesicles. Nephrology Dialysis Transplantation. 2012 Aug 1;27(8).

3. Lai RC, Yeo RWY, Tan KH, Lim SK. Exosomes for drug delivery - a novel application for the mesenchymal stem cell. Biotechnology Advances. 2013 Sep;31(5).

4. GutierrezaMillan C, Calvo Díaz C, Lanao JM, Colino Cl. Advances in ExosomesuBased Drug Delivery Systems. Macromolecular Bioscience. 2021 Jan 22;21(1).

5. Semedo P, Burgos-Silva M, Donizetti-Oliveira C, Saraiva Camar NO. How do Mesenchymal Stem Cells Repair? In: Stem Cells in Clinic and Research. InTech; 2011.

6. Güneş S, Uysal O, Sevimli T, Sevimli M, Tokhi A, Sarıboyacı A. Kök Hücreler. In: Avci H, editor. Polimerler: Özellikleri ve Uygulamaları. 1st ed. ESOGU; 2021. p. 325-49.

7. Song Y, Kim Y, Ha S, ShelleraMiller S, Yoo J, Choi C, et al. The emerging role of exosomes as novel therapeutics: Biology, technologies, clinical applications, and the next. American Journal of Reproductive Immunology. 2021 Feb $12 ; 85(2)$.

8. E Z, G. M, Momen-Heravi F, Hu J, Zhang X, Wu Y, et al. Therapeutic uses of exosomes. Exosomes and Microvesicles. 2013

9. Watanabe Y, Tsuchiya A, Terai S. The development of mesenchymal stem cell therapy in the present, and the perspective of cell-free therapy in the future. Clinical and Molecular Hepatology. 2021 0ct;27(1)

10. Khan M, Nickoloff E, Abramova T, Johnson J, Verma SK, Krishnamurthy P, et al. Embryonic Stem Cell-Derived Exosomes Promote Endogenous Repair Mechanisms and Enhance Cardiac Function Following Myocardial Infarction. Circulation Research. 2015 Oct;117(1).
11. Ranghino A, Bruno S, Bussolati B, Moggio A, Dimuccio $V$, Tapparo $M$, et al. The effects of glomerular and tubular renal progenitors and derived extracellular vesicles on recovery from acute kidney injury. Stem Cell Research \& Therapy. 2017 0ct;8(1).

12. McBride JD, Rodriguez-Menocal L, Guzman W, Candanedo A, Garcia-Contreras M, Badiavas E v. Bone Marrow Mesenchymal Stem Cell-Derived CD63 + Exosomes Transport Wnt3a Exteriorly and Enhance Dermal Fibroblast Proliferation, Migration, and Angiogenesis In Vitro. Stem Cells and Development. 2017 0ct;26(19).

13. Zhang S, Chuah SJ, Lai RC, Hui JHP, Lim SK, Toh WS. MSC exosomes mediate cartilage repair by enhancing proliferation, attenuating apoptosis and modulating immune reactivity. Biomaterials. 2018 0ct;156.

14. Yao J, Zheng J, Cai J, Zeng K, Zhou C, Zhang J, et al. Extracellular vesicles derived from human umbilical cord mesenchymal stem cells alleviate rat hepatic ischemia reperfusion injury by suppressing oxidative stress and neutrophil inflammatory response. The FASEB Journal. 2019 0ct;33(2).

15. Li X, Liu L, Yang J, Yu Y, Chai J, Wang L, et al. Exosome Derived From Human Umbilical Cord Mesenchymal Stem Cell Mediates MiR-181c Attenuating Burn-induced Excessive Inflammation. EBioMedicine. 2016 0ct;8.

16. Fujii S, Miura Y, Fujishiro A, Shindo T, Shimazu Y, Hirai $H$, et al. Graft-Versus-Host Disease Amelioration by Human Bone Marrow Mesenchymal Stromal/Stem Cell-Derived Extracellular Vesicles Is Associated with Peripheral Preservation of Naive T Cell Populations. STEM CELLS. 2018 Oct;36(3).

17. Fan $Y$, Herr F, Vernochet A, Mennesson B, Oberlin E, Durrbach A. Human Fetal Liver Mesenchymal Stem CellDerived Exosomes Impair Natural Killer Cell Function. Stem Cells and Development. 2019 0ct;28(1).

18. Kulkarni R, Bajaj M, Ghode S, Jalnapurkar S, Limaye L, Kale VP. Intercellular Transfer of Microvesicles from Young Mesenchymal Stromal Cells Rejuvenates Aged Murine Hematopoietic Stem Cells. STEM CELLS. 2018 Oct;36(3). 
19. Liu W, Tang $P$, Wang J, Ye W, Ge X, Rong $Y$, et al. Extracellular vesicles derived from melatonin $\square$ preconditioned mesenchymal stem cells containing USP29 repair traumatic spinal cord injury by stabilizing NRF2. Journal of Pineal Research. 2021 Oct;

20. Wang X, Omar O, Vazirisani F, Thomsen P, Ekström K. Mesenchymal stem cell-derived exosomes have altered microRNA profiles and induce osteogenic differentiation depending on the stage of differentiation. PLOS ONE. 2018 Oct;13(2).

21. Cui G, Wu J, Mou F, Xie W, Wang F, Wang Q, et al. Exosomes derived from hypoxiaDpreconditioned mesenchymal stromal cells ameliorate cognitive decline by rescuing synaptic dysfunction and regulating inflammatory responses in APP/PS1 mice. The FASEB Journal. 2018 $0 c t ; 32(2)$.

22. Abello J, Nguyen TDT, Marasini R, Aryal S, Weiss ML. Biodistribution of gadolinium- and near infrared-labeled human umbilical cord mesenchymal stromal cell-derived exosomes in tumor bearing mice. Theranostics. 2019;9(8).

23. Wiklander OPB, Nordin JZ, O'Loughlin A, Gustafsson $Y$, Corso G, Mäger I, et al. Extracellular vesicle in vivo biodistribution is determined by cell source, route of administration and targeting. Journal of Extracellular Vesicles. 2015 0ct;4(1).

24. Patel NA, Moss LD, Lee J-Y, Tajiri N, Acosta S, Hudson $C$, et al. Long noncoding RNA MALAT1 in exosomes drives regenerative function and modulates inflammation-linked networks following traumatic brain injury. Journal of Neuroinflammation. 2018 0ct;15(1).

25. Kim D, Nishida H, An SY, Shetty AK, Bartosh TJ, Prockop DJ. Chromatographically isolated CD63 + CD81 + extracellular vesicles from mesenchymal stromal cells rescue cognitive impairments after TBI. Proceedings of the National Academy of Sciences. 2016 0ct;113(1).

26. Xin H, Katakowski M, Wang F, Qian J-Y, Liu XS, Ali MM, et al. MicroRNA-17-92 Cluster in Exosomes Enhance Neuroplasticity and Functional Recovery After Stroke in Rats. Stroke. 2017 0ct;48(3).
27. de Godoy MA, Saraiva LM, de Carvalho LRP, Vasconcelos-dos-Santos A, Beiral HJ v, Ramos AB, et al. Mesenchymal stem cells and cell-derived extracellular vesicles protect hippocampal neurons from oxidative stress and synapse damage induced by amyloid- $\beta$ oligomers. Journal of Biological Chemistry. 2018 Oct;293(6).

28. Liu W, Wang Y, Gong F, Rong Y, Luo Y, Tang $P$, et al. Exosomes Derived from Bone Mesenchymal Stem Cells Repair Traumatic Spinal Cord Injury by Suppressing the Activation of A1 Neurotoxic Reactive Astrocytes. Journal of Neurotrauma. 2019 Oct;36(3).

29. Ruppert KA, Nguyen TT, Prabhakara KS, Furman NET, Srivastava AK, Harting MT, et al. Human Mesenchymal Stromal Cell-Derived Extracellular Vesicles Modify Microglial Response and Improve Clinical Outcomes in Experimental Spinal Cord Injury. Scientific Reports. 2018 Oct;8(1).

30. Sun G, Li G, Li D, Huang W, Zhang R, Zhang H, et al. hucMSC derived exosomes promote functional recovery in spinal cord injury mice via attenuating inflammation. Materials Science and Engineering: C. 2018 Aug;89.

31. Adamiak M, Cheng G, Bobis-Wozowicz S, Zhao L, Kedracka-Krok S, Samanta A, et al. Induced Pluripotent Stem Cell (iPSC)-Derived Extracellular Vesicles Are Safer and More Effective for Cardiac Repair Than iPSCs. Circulation Research. 2018 0ct;122(2).

32. Wang $N$, Chen $C$, Yang D, Liao Q, Luo $H$, Wang $X$, et al. Mesenchymal stem cells-derived extracellular vesicles, via miR-210, improve infarcted cardiac function by promotion of angiogenesis. Biochimica et Biophysica Acta (BBA) - Molecular Basis of Disease. 2017 Aug;1863(8).

33. Zhu J, Lu K, Zhang N, Zhao Y, Ma Q, Shen J, et al. Myocardial reparative functions of exosomes from mesenchymal stem cells are enhanced by hypoxia treatment of the cells via transferring microRNA-210 in an nSMase2dependent way. Artificial Cells, Nanomedicine, and Biotechnology. 2017 Oct;

34. Sun X, Shan A, Wei Z, Xu B. Intravenous mesenchymal stem cell-derived exosomes ameliorate myocardial inflammation in the dilated cardiomyopathy. Biochemical and Biophysical Research Communications. 2018 0ct;503(4). 
35. Potter DR, Miyazawa BY, Gibb SL, Deng X, Togaratti PP, Croze RH, et al. Mesenchymal stem cell-derived extracellular vesicles attenuate pulmonary vascular permeability and lung injury induced by hemorrhagic shock and trauma. Journal of Trauma and Acute Care Surgery. 2018 0ct;84(2).

36. Tang X-D, Shi L, Monsel A, Li X-Y, Zhu H-L, Zhu Y-G, et al. Mesenchymal Stem Cell Microvesicles Attenuate Acute Lung Injury in Mice Partly Mediated by Ang-1 mRNA. STEM CELLS. 2017 Jul;35(7).

37. Sengupta V, Sengupta S, Lazo A, Woods $P$, Nolan A, Bremer N. Exosomes Derived from Bone Marrow Mesenchymal Stem Cells as Treatment for Severe COVID19. Stem Cells and Development. 2020 0ct;29(12).

38. Younis N, Zarif R, Mahfouz R. Inflammatory bowel disease: between genetics and microbiota. Molecular Biology Reports. 2020 0ct;47(4).

39. Cai X, Zhang Z, Yuan J, Ocansey DKW, Tu Q, Zhang X, et al. hucMSC-derived exosomes attenuate colitis by regulating macrophage pyroptosis via the miR-378a-5p/NLRP3 axis. Stem Cell Research \& Therapy. 2021 0ct;12(1).

40. Barnhoorn MC, Plug L, Jonge ESMM, Molenkamp D, Bos E, Schoonderwoerd MJA, et al. Mesenchymal Stromal CellDerived Exosomes Contribute to Epithelial Regeneration in Experimental Inflammatory Bowel Disease. Cellular and Molecular Gastroenterology and Hepatology. 2020;9(4).

41. Haga H, Yan IK, Takahashi K, Matsuda A, Patel T. Extracellular Vesicles from Bone Marrow-Derived Mesenchymal Stem Cells Improve Survival from Lethal Hepatic Failure in Mice. STEM CELLS Translational Medicine. 2017 0ct;6(4).

42. Tamura R, Uemoto S, Tabata $\mathrm{Y}$. Immunosuppressive effect of mesenchymal stem cell-derived exosomes on a concanavalin A-induced liver injury model. Inflammation and Regeneration. 2016 0ct;36(1).

43. Rigo F, Stefano N de, Navarro-Tableros V, David E, Rizza G, Catalano G, et al. Extracellular Vesicles from Human Liver Stem Cells Reduce Injury in an Ex Vivo Normothermic Hypoxic Rat Liver Perfusion Model. Transplantation. 2018 Oct;102(5).
44. Li T, Yan Y, Wang B, Qian H, Zhang X, Shen L, et al. Exosomes Derived from Human Umbilical Cord Mesenchymal Stem Cells Alleviate Liver Fibrosis. Stem Cells and Development. 2013 0ct;22(6).

45. Yan $Y$, Jiang $W$, Tan $Y$, Zou S, Zhang H, Mao F, et al. hucMSC Exosome-Derived GPX1 Is Required for the Recovery of Hepatic Oxidant Injury. Molecular Therapy. 2017 Oct;25(2).

46. Moisseiev E, Anderson JD, Oltjen S, Goswami M, Zawadzki RJ, Nolta JA, et al. Protective Effect of Intravitreal Administration of Exosomes Derived from Mesenchymal Stem Cells on Retinal Ischemia. Current Eye Research. 2017 0ct;42(10).

47. Shen $T$, Zheng $Q-Q$, Shen J, Li Q-S, Song $X-H$, Luo H-B, et al. Effects of Adipose-derived Mesenchymal Stem Cell Exosomes on Corneal Stromal Fibroblast Viability and Extracellular Matrix Synthesis. Chinese Medical Journal. 2018 0ct;131(6).

48. Yuan X, Li D, Chen X, Han C, Xu L, Huang T, et al. Extracellular vesicles from human-induced pluripotent stem cell-derived mesenchymal stromal cells (hiPSCMSCs) protect against renal ischemia/reperfusion injury via delivering specificity protein (SP1) and transcriptional activating of sphingosine kinase 1 and inhibiting necroptosis. Cell Death \& Disease. 2017 Oct;8(12).

49. Tomasoni S, Longaretti L, Rota C, Morigi M, Conti S, Gotti E, et al. Transfer of Growth Factor Receptor mRNA Via Exosomes Unravels the Regenerative Effect of Mesenchymal Stem Cells. Stem Cells and Development. 2013 0ct;22(5). 